Moreover, a time-lag has been built into the decree, presumably to allow the Soviet Union to acquire the necessary technology. No off-shelf operations, it states, can begin before 1 January 1988.

Several clauses deal with possible nonSoviet participation in off-shelf operations. This would presumably be of two types - with developed and with developing countries. One likely partner in the first category is East Germany, with which the Soviet Union (together with Poland) is already linked in the Baltic drilling consortium Petrobaltyk to which the Germans have made a considerable technological contribution. The decree, however, stresses the Soviet Union's role in "assisting" its future partner in the development of technology and the training of personnel, suggesting participation by developing countries. (This would fit in with Kozyrev's rejection of the "colonial" overtones of the Western proposals.)

The developing country would in the first instance presumably provide a shore base and other facilities. Any minerals recovered, according to the decree, would become Soviet property, though in some cases, some or all of them could revert to

\title{
Conference all at sea
}

\section{Washington}

The largest ever diplomatic conference of the United Nations, with 160 governments represented, ended on 30 April in New York with a huge majority for a draft treaty on the Law of the Sea. But the participants in this eight-year-long conference have not gone home in triumph. Instead, they hope to limit the damage that has been done.

What went wrong? In the end, the United States voted against the treaty, as did Israel, Turkey and Venezuela. Britain, West Germany, the Netherlands, Belgium, Spain and the entire Eastern bloc abstained. Ironically, even the dissenters think the draft is a splendid basis for a treaty. It resolves several complex issues, such as navigation through narrow straits.

The stumbling block turned out to be the issue well advertised in the past few years: the rights of private companies to minerals from the deep sea bed. Both the United States and the Soviet Union were affronted. The new Administration in Washington had spent a year trying to decide how to amend the clauses on international access to oceanic minerals that the Carter Administration had negotiated. The Soviet Union, by contrast, objected to a form of words seeming to cast doubt on its freedom from free enterprise.

What happens now is anybody's guess. The procedure requires that governments wishing to sign the treaty must do so by December. Thereafter, the treaty will become international law when a specified quota of signatories has formally ratified it. The flaw is that because the draft of the treaty was not approved without dissent, it is open to any member of the conference to insist that the text cannot be a basis for international law because it was disputed.

So who shoulders the blame? The outcome of the conference was a failure for the diplomats. The bizarre handling of the United States negotiating team may have been crucial.

The Law of the Sea session just ended lasted just eight weeks, and brought to an end the year-long spell during which the United States Administraiton had put the negotiations on ice.
Private seabed mining has been the only stumbling block. Ideologically, the Administration objected to those parts of the text that would give developing countries a say over the private development of seabed minerals. But among the six objections listed by the United States when it returned to the negotiations in January were the provision that the treaty could be amended by threequarters of its signatories without the US Senate's agreement, and the inclusion of the Palestine Liberation Organization among the members of the conference.

After the event, US negotiators claim that they were not given enough time to negotiate the real issues. The conference chairman, Tommy Koh of Singapore, made them stick to a prearranged timetable. The deadline of 29 March had early on been fixed for the filing of committee reports on which a final draft would be drawn up. By then, however, the mining committee had not agreed a resolution on seabed mining, while the constitutional objection to changing the treaty without consent of the US Congress had not been discussed.

Part of the difficulty seems to rest with the makeup of the US negotiating team. Its leader was James L. Malone, an assistant secretary at the State Department whom the Administration was stripping of his responsibility for nuclear nonproliferation. Malone's chief aide was Leigh Ratiner, a former government seabed mining expert working for the mining industry,

Ratiner was a free-wheeling negotiator and a veteran of earlier sessions at the law of the sea conference. Malone was by comparison a novice. Observers say that Malone would often say one thing and Ratiner another. The result would be either brilliant or confusing, depending on the observer. The delegation was under constant pressure from the mining lobby, which insisted that any sell-out to the conference would be denounced when the treaty came up for ratification in Congress.

The United States' demands for revisions of the treaty, circulated before the beginning of the last session in March, the partner state. The concept of the Soviet Union building up Third-World off-shelf technology would, however, become particulary relevant if an international agreement were drawn up dividing the offshelf zone between the interested countries. In that case, the "temporary measures" now announced would automatically lapse. But existing collaboration agreements between the Soviet Union and developing countries on mining activities normally provide for the Soviet Union's initial investment in the technology being repaid over several decades in appropriate minerals. Vera Rich

were quickly followed up by detailed textual proposals - and as quickly rejected as too sweeping. A compromise proposal, put forward by 11 states including Australia, Canada, Denmark, Finland, Iceland, Ireland, New Zealand, Norway, Sweden and Switzerland, was quickly rejected by the United States as inadequate but later recognized to be a basis for discussion. By then, however, it was too late.

What will happen now is far from clear. The ceremony at which the treaty will be opened for signature has been arranged for Caracas in December, but the host country, Venezuela, voted against the draft last month because if fails to resolve the dispute with neighbouring Colombia.

No state is bound by the vote it cast on 30 April. Abstaining states or no-voting states could still attend the signing ceremony. But Israel's no is unlikely to change, as the PLO no seems likely to stay in the final text. The Reagan Administration could not change the US vote without an ideological turnabout, which seems unlikely.

Ironically, the Administration's adamant defence of rights to ocean mining may have brought about a situation in which no mining is possible. Tommy Koh has threatened to sue any country that proceeds unilaterally to mine outside the framework of the Law of the Sea. So, if the United States, and other mining states such as the United Kingdom, remain out of the fold, they may see their mining ventures flee to other countries such as Japan.

Meanwhile Elliot L. Richardson, Law of the Sea negotiator for the Carter Administration, believes that the outcome of the conference is "sad". Richardson said that "ideologues" in and outside the Reagan Administration prevented the US negotiating team from being flexible.

The Administration, he said, "wasted" a year deciding whether to continue negotiating, and so spent too little time preparing for the talks themselves. At the meeting at which the US team agreed to produce specific draft articles, it had run out of time and had to include many items that it knew were unacceptable. Similarly, Richardson believes the US team should not have responded so negatively to efforts by a group of eleven countries to negotiate compromises. 